\title{
SMOOTH GOOSEFOOT DISCOVERED IN THE WEBB SANDHILLS
}

DIANA BIZECKI ROBSON, 2113 Aird Street, Saskatoon, SK S7N 0T3

While conducting research for a Master's thesis project on rare plants, I discovered three new populations of Smooth Goosefoot (Chenopodium subglabrum (S. Wats.) A. Nels.) in the sandhills north of Webb, Saskatchewan. As Smooth Goosefoot is considered to be a vulnerable (i.e. could become threatened or endangered under current conditions) species by the Committee on the Status of Endangered Wildlife in Canada (COSEWIC), this discovery is particularly important.

A voucher specimen was collected only at the first site as I did not want to endanger the populations by re- moving more specimens. The voucher specimen is on file in the W.P. Fraser Herbarium, University of Saskatchewan, Saskatoon, SK. Pictures were taken at the remaining two sites to document the sighting (Figure 1).

Smooth Goosefoot is an annual, wind-pollinated plant that is found on active or semi-stabilized sand dune blowouts. The plant is erect to semierect with ascending branches ${ }^{1}$ (Figure 2). The leaves are fleshy, linear, entire, one-veined and hairless or slightly powdery. ${ }^{1}$ The inflorescence is open and leafy with small flowers in clusters called glomerules. ${ }^{1}$ The



Figure 1. Habitat of Smooth Goosefoot on a sand dune blowout 
plants flower late in the summer, and are found in southeastern Alberta, southern Saskatchewan and southwestern Manitoba.

I discovered the first population of Smooth Goosefoot on 23 July 1996 in a PFRA pasture 12 miles (19 km) northeast of Webb (SW1/4 S26 T15 R16 W3). There were 55 plants randomly distributed on a mobile sand dune blowout. This blowout also contained two other provincially rare plants: Bur Ragweed (Franseria acanthicarpa) and Annual Skeletonweed (Lygodesmia rostrata).

On 24 July 1996, a small population was found in a dune blowout 4.5 miles $(7 \mathrm{~km})$ north of Webb (SW1/4 S6 T15 R16 W3). There were 39 Smooth Goosefoot plants in this area. As well, populations of three other provincially rare plants were present: Sanddune Wheatgrass (Agropyron dasystachyum var. psammophilum), Bur Ragweed and Annual Skeleton-weed.

Smooth Goosefoot was found again the following day (25 July 1996) on a mobile sand dune blowout six miles $(10 \mathrm{~km})$ north of Webb (S18 T15 R16 W3). Only 13 individuals were found at this location. Annual Skeleton-weed also occurred in this habitat.

Smooth Goosefoot was associated with a number of common dune species: Scurf Pea (Psoralea lanceolata), Indian Rice (Oryzopsis hymenoides), Canada Wild Rice (Elymus canadensis) and Sand Dock (Rumex venosus).

Most dune plants are early successional species which help stabilize eroding dunes. Ironically, dune plants are experiencing a loss of habitat due to this stabilization. The



Figure 2. Smooth Goosefoot (Chenopodium subglabrum)

dominant cause of dune stabilization is long-term climatic change. ${ }^{2}$ Over the last few centuries, there has been a climatic cooling trend which has promoted stabilization.

Prior to the discovery of three populations of Smooth Goosefoot near Webb, this species had been found mainly in the dunes along the South Saskatchewan River valley (Figure 3). Smooth Goosefoot's detection in the Webb sandhills suggests that it may be more widespread than previously thought. Continued monitoring of known populations and botanical field surveys of other dune areas in the prairie provinces will help to determine the true status and distribution of this plant.

Acknowledgements. I would like to thank the Prairie Ecosystem Study and the Heritage Foundation for their financial support of my research. 




\section{Chenopodium subglabrum (SMOOTH ARID GOOSEFOOT)}

- PREVIOUS POPULATIONS

a NEW POPULATIONS

Figure 3. Distribution of Smooth Goosefoot in Saskatchewan.

1. MOSS, E.H. 1983. Flora of Alberta, second edition. University of Toronto Press, Toronto.
2. SAUCHYN, D.J. 1993. Quaternary and late tertiary landscapes of southwestern Saskatchewan and adjacent areas. Canadian Plains Research Center, University of Regina, Regina, Saskatchewan. 